\title{
LENGTH-WEIGHT RELATIONSHIPS AND CONDITION FACTORS OF SIX FISH SPECIES IN ATBARA RIVER AND KHASHM EL- GIRBA RESERVOIR, SUDAN
}

\author{
EGBAL 0. AHMED ${ }^{1 *}$, MOHAMMED E. ALI² AND AFRA A. AZIZ1 \\ ${ }^{1}$ Department of Fish Science, Faculty of Agricultural Technology and Fish Science, University of Elneelain, Khartoum, \\ Sudan, P.O. Box: 12702 \\ 2Fisheries Research Centre, (AL shagara) Khartoum, P. O. Box: 1489 \\ *Corresponding Author: Email - egbalosman@hotmail.com
}

Received: May 16, 2011; Accepted: June 11, 2011

\begin{abstract}
This study describes the length-weight relationships (LWR) and condition factors of six fish species from six families of ecological and economic importance, found in Atbara River and Khashm el- Girba reservoir. A total of 1118 specimens were caught by using various mesh size of gill nets from January, 2007 to December, 2007. The growth coefficient (b) values obtained for the six fish species ranged between 2.278 for Clarias lazera and 3.680 for Bagrus bayad and differed significantly $(p<0.005)$ from 3 , which indicates that most of the fish species $(61.1 \%)$ have negative allometric growth. The condition factors $(K)$ of the fish species ranged from $(0.506 \pm 0.416)$ in Clarias lazera to (3.415 \pm 0.707$)$ in Oreochromis niloticus and about $83.3 \%$ of these condition factors fall outside the range recommended as suitable for matured fresh water fish species in the tropics.
\end{abstract}

Key words: Freshwater fish species, Atbara River, Khashm el- Girba reservoir, length-weight relationship, Condition factor, allometric growth.

\section{INTRODUCTION}

Data on the length and weight of fish have commonly been analysed to yield biological information. The length-weight relationship (LWR) is very important for proper exploitation and management of the population of fish species [6]. LWR has a number of important applications in fish stock assessment [27]. To obtain the relationship between total length and other body weight are also very much essential for stabilizing the taxonomic characters of the species [30]. [29] stated that LWR provides valuable information on the habitat where the fish lives while [21] stressed the importance of LWR in modeling aquatic ecosystems. Length and weight data are a useful and standard result of fish sampling programs. Furthermore, standing crop biomass can be estimated [26] and seasonal variations in fish growth can be tracked this way [31] However, the length-weight parameters of the same species may be different in the population because of feeding, reproduction activities and fishing etc. Therefore, data on functional LWR of fish species is important for fish stock assessment and parameters a and $b$ can be used for length-weight conversion [17]. At the same time, the relationship of length-weight estimates condition factor (c.f.) of the fish species and fish biomass through the length frequency [12]. In fisheries science, the condition factor is used in order to compare the "condition", "fatness" or wellbeing of fish. It is based on the hypothesis that heavier fish of a particular length are in a better physiological condition[9]. Condition factor is also a useful index for monitoring of feeding intensity, age, and growth rates in fish[28]. It is strongly influenced by both biotic and a biotic environmental conditions and can be used as an index to assess the status of the aquatic ecosystem in which fish live [6]. Condition factors of different tropical fish species were investigated and reported by $[33,5$, 1- 2].

Despite the usefulness of length-weight relationship and condition factor in fisheries science and the importance of the Khashm el- Girba reservoir to the fisheries of the eastern Sudan, information about the length-weight relationships and condition factors of fish species in Atbara River and Khashm el- Girba reservoir are non-existent. The paucity of these information propelled this study, which is aimed at bridging this gap and also provide useful information for the management of Khashm el- Girba reservoir fisheries.

\section{MATERIALS AND METHODS}

Sampling Area: The fish samples were obtained from the two different locations i.e. the Atbara River and Khashm el- Girba reservoir.

The Atbara River, a tributary of the Nile, which forms one of the five sub-basins of the Nile System within Sudan. Atbara River is characterized by strongest seasonality and extreme flow regime compared with the other rivers[18]. It's origin and main portion is situated on the Ethiopian High Plateau between $12^{\circ} \mathrm{N}$ to $15^{\circ} \mathrm{N}$ and $36^{\circ} \mathrm{E}$ (Fig 1).

The Khashm el- Girba reservoir is located in an arid zone at the eastern Sudan and lies at $14^{\circ} 55^{\prime} 35^{\prime \prime} \mathrm{N}$ and $35^{\circ} 53^{\prime} 20^{\prime \prime} \mathrm{E}$ (Fig 1). It was constructed across 
the Atbara River in 1964, mainly to provide irrigation for the population displaced by the rising water of Lake Nubia (the southern part of the High Dam Reservoir) on the Nile River. Fisheries conservation in the damreservoir has a special problem, because each year it is flushed to remove silt and debris, as a result of which the fish population suffers great losses every year [14]. This is through mass mortality due to the high speed of current and the blockage of gills by silt in addition to carrying over part of the population downstream.

Sampling of Fish: A total of 1,118 fish samples belonging to 6 families (Bagridae, Auchenoglanidinae, Cichildae, Mochokidae,Cyprinidea, and Clariidae) were collected randomly from the sampling stations, Atbara River(Umaswad) and The Khasim el-Girba reservoir (Remaila\&Bwadra) were shown in (Fig. 1) between January, 2007 and December, 2007. The fisher folks operating in this reservoir deploy surface and bottom set gillnets using various mesh size ranging from 5.0,7.3, 8.8,10.0 and $12 \mathrm{~cm}$. The Fish were obtained from both sampling locations were identified using keys provided by [11, 34, 8, 3-12].

Total length $(\mathrm{cm})$ of each fish was taken from the tip of the snout (mouth closed) to the extended tip of the caudal fin using a measuring board. Body weight was measured to the nearest gram using Electronic Digital Balance (KRUTPS TYPE 875).

Parameters of the length-weight relationship of identified fish species were estimated using the equation:

$$
\mathrm{W}=\mathrm{aL} \mathrm{b}^{\mathrm{b}} \text { [32] (1) }
$$

where,

$\mathrm{W}=$ Weight of fish $(\mathrm{g})$

$\mathrm{L}=$ Length of fish $(\mathrm{cm})$

$\mathrm{a}=\mathrm{y}$-intercept or the initial growth coefficient

$b=$ Slope or the growth coefficient.

The values of constants $a$ and $b$ were estimated after logarithmic transformation of Eq. (1) using least square linear regression [36] to give:

$$
\log W=\log _{10} a+b \log _{10} L(2)
$$

Prior to regression analysis of $\log W$ on $\log \mathrm{L}, \log -\log$ plots of length and weight values were performed for visual inspection of outliers (Froese, 2006). Only extreme outliers attributed to data error were omitted from analyses. The 95\% confidence interval, $\mathrm{Cl}$ of $\mathrm{b}$ was computed using the equation:

$$
\mathrm{Cl}=\mathrm{b} \pm(1.96 \times \mathrm{SE})
$$

Where, SE is the standard error of $b$.

The condition factor was calculated by the formula:

Condition Factor $(K)=100 W L^{3}$ [29]

Where, $\mathrm{W}=$ weight in grams; $\mathrm{L}=$ total length $(\mathrm{cm})$.
Data Analysis:

Variations in the length-weight relationship (represented by 'b') and condition factor (represented by $\mathrm{K}$ ) of the individual fish living in the two locations were described throughout the year. Relationship between length and weight of the fish was examined by simple linear regression analysis. The nonparametric Kruskal-Wallis test (One-way Analysis of Variance) was conducted to perform comparisons the condition of fish between the different sampling sites. The minimum significant level for the relevant test was set at $p<0.05$.

\section{RESULTS AND DISCUSSION}

Result: The length-weight distribution of the six major fish species collected from the Atbara River and Khashm el- Girba reservoir were analysed in this study. The species, length-weight relationship parameters $a$ and $b, 95 \%$ confidence interval for $b$, correlation coefficient $(r)$ were presented in table 1 ,while number of specimens, min-max length, minmax weight and condition factor of fish species were presented in Table 2. The estimated value of allometry coefficient (b) ranged between 2.278 for Clarias lazera and 3.680 for Bagrus bayad. The values of correlation coefficient $(r)$ varied from 0.749 in Bagrus bayad to 0.998 in Clarias lazera. $33.3 \%$ of the species had $r>0.90,61.1 \%$ had $r$ values between $0.80-0.90$ while $5.5 \%$ had $r$ values lower than 0.80 . The lengths ranged from 12 to $93 \mathrm{~cm}$ while the weights were between 125 and $2100 \mathrm{~g}$. Synodontis schall had the highest number of fish sample, $n=270$ with the maximum $\mathrm{TL}=83 \mathrm{~cm}$ and $\mathrm{W}=900 \mathrm{~g}$. Auchenoglanis biscutatus was the smallest size group, $\mathrm{n}=108$ ranging from 20 to $45 \mathrm{~cm}$ in TL and weight ranging between 75 and $1100 \mathrm{~g}$. The largest species was Clarias lazera with the $\mathrm{TL}$ ranging from 26 to $93 \mathrm{~cm}$ and weight ranging between 125 and $2100 \mathrm{~g}$. The lowest condition factor $(K)(0.506 \pm 0.416)$ was recorded in Clarias lazera while the highest value $(3.415 \pm 0.707)$ was observed in Oreochromis niloticus.

\section{Discussion}

The slopes $(b)$ of the fish L-W regression lines from both the Atbara River and Khashm el- Girba reservoir fell within 2.278 and 3.680 this within the value recorded by [30] that ranged from 2.5 to 4.0 for many fish species. When $b=3$, the fish grows isometrically resulting in ideal shape of fish. Such value was not observed for all fish collecting from the both areas in this study. When the value of $b$ is less than 3.0, the fish experiences a negative allometric growth [35]. Labeo niloticus, Synodontis schall \& Oreochromis niloticus from Atbara River and Labeo niloticus , Auchenoglanis biscutatus from two stations in the reservoir in addition to Synodontis schall , Bagrus bayad and Oreochromis niloticus , Clarias lazera from Remaila \& Bwadra stations respectively suffered from this pattern of growth. When the value of $b$ is more than 3.0, the fish grow following the positive allometric 
pattern. Some fish species such as Auchenoglanis biscutatus ,Clarias lazera \& Bagrus bayad in Atbara River, Bagrus bayad, Synodontis schall and Oreochromis niloticus , Clarias lazera from Bwadra \& Remaila stations respectively from the reservoir had positive allometric growth. As the values of $b$ increases, the size of the fish also increases because the fish usually grows proportionately in all directions. However, the changes in fish weight in general are actually greater than the changes in its length. However, the body shape of fish tends to change as the length increases. The value of $b$ then becomes greater than 3 as the fish becomes fatter, or when the $b$ value is lower than 3 , the fish is slimmer[19]. The $95 \%$ confidence interval of $b$ for all the fish species ranged from 2.438 to 3.953. Similar results were recorded by [25] who studied the length weight relationships of 12 freshwater fish species in the Kerian River basin and Pedu Lake and reported $95 \% \mathrm{Cl}$ of $\mathrm{b}$ values that ranged from 2.329 to 3.919 . The correction coefficient ( $r$ ) for length weight relationships for both area is high for all fish species which indicates that the length increases with increase in weight of the fish. This is in agreement with previous studies on different fish species from various water bodies: [15, 22-4].

The length-weight distributions of fishes from both locations; the Atbara River and Khashm el- Girba reservoir showed considerably large variations in fish sizes indicating that the samplings with gill nets were carried out efficiently. Selection of mesh size of nets also contributed to the minimum-maximum length of fish caught $(12-93 \mathrm{~cm})$ hence the weight which ranged from 25 to $2100 \mathrm{~g}$. The size of the fish captured ranged from the smallest to the biggest and from young to adult stages with differences in their growth rates. The condition factor $(\mathrm{K})$ reflects, through its variations, information on the physiological state of the fish in relation to its welfare. From a nutritional point of view, there is the accumulation of fat and gonad development [23]. From a reproductive point of view, the highest $K$ values are reached in some species [7]. The condition factors $(K)$ of the 6 fish species ranged between 0.506 and 3.415. A closer examination of the condition factors revealed that $83.3 \%$ (5 out of 6 fish species) of the fish species had their $K$ values outside the range (2.9-4.8) recommended as suitable for matured fresh water fish by [9]. This could have been caused by adverse environmental factors. That Khashm el-Girba reservoir has been flushed annually, because it faces serious siltation problem, which is very critical in the sense that the reservoir is losing storage capacity at an average rate of 40 million $\mathrm{m}^{3} /$ year. In this process complete drainage of the reservoir occurs within approximately nine hours when the dam gates are fully opened [13]. During the flushing process massive mortality of fish occurs, the process is a detrimental factor which affects various fish populations as considerable amount of fish was lost in the reservoir. For this reason suggests that the condition of Khashm el-Girba reservoir in comparison to fresh water bodies may be unfavourable to fishes in the reservoir. Therefore, there would be need for more studies on the relationships and condition factors of some fish species in the reservoir and Atbara River.

\section{CONCLUSION}

In conclusion, the present studies found that each species of fish inhabiting the Khashm el-Girba reservoir and Atbara River had different length and weight relationship due to factors such as differences in length and body weight, differences in food availability in lotic and lentic environments and other environmental conditions. More of the fish species had nagitive allometric growth. An important contribution of this study is the provision of base line data on the length-weight relationship in Khashm el-Girba reservoir and Atbara River

\section{ACKNOWLEDGMENT}

The authors are grateful to the Head, Fisheries Administration, Khashm el-Girba, Ministry of Agriculture and Animal Resources, Kasala State for approving the use of the Laboratory and providing the necessary materials for the study.

\section{REFERENCES}

[1] Abowei J.F.N. and Davies A.O. (2009) J. Sci. Res, (2): 15-19.

[2] Abowei J.F.N. (2010) Adv. J. Food. Sci \&Tech, (1): 16-21.

[3] Abu Gideri Y.B. (1984) Fishes of Sudan. Sudan, Khartoum University. Press (166p).

[4] Ayoade A.A. and Ikulala A.O.O. (2007) In. J. Tro. Bio, 55 (3-4): 969-977.

[5] Alfred-Ockiya J.F. and Njoku D.C. (1995) J. Tech. Educ, pp: 5-10.

[6] Anene A. (2005) Turk. J. Fish. Aquat. Sci, 5: $43-47$.

[7] Angelescu V., Gneri F.S. and Nani A. (1958) La del Mar Argentine hake (biology and taxonomy). Hydro gels. Nav. Public., H1004: 1-224.

[8] Bailey R.G. (1994) Guide to fishes of the River Nile in the republic of the Sudan. College of London. UK. pp: 944-947.

[9] Bagenal T.B. and Tesch F.W. (1978) Methods of Assessment of Fish Production in Fresh Waters. IBP Handbook No 3, 3rd ed. Oxford Blackwell Scientific Publication, London. pp: 101-136.

[10] Boulenger G.C.A. (1909) The fishes of Nile. Zoology of Egypt. Hugh Rees Ltd., London.

[11] Cherif M., Zarrad R., Gharbi H, Missaoui H. and Jarboui O. (2008) Pan-American J. of Aquatic Sciences, 3(1): 1-5.

[12] FISHBASE (www.fishbase.com). Online fish identification sheet. Available at 
[13] http://www.fishbase.org/search.phpp

[14] El-Moghraby A. I., Mishrigi S.Y. and Kheir H. (1993) Report on the impact of the flushing of Khashm el-Girba reservoir on fisheries resources and its socio-economic on riparian communities. Sudan Environment, Conservation Society. pp 14-33

[15] Everett G.V. (1995) Sudan Fisheries: An Assessment of the Situation and Proposal for Future, with Emphasis Given on Inland Fisheries. FAO Fisheries, Circular No 901:88p.

[16] Fagade S.O. (1983) Arch. Hydrobiol., 97:6072.

[17] Froese R. (2006) J. Appl. Ichthyol, 22: 241253.

[18] Hajjej G., Hattour A., Allaya H., Cherif M., Bouain A. and Jarboui O. (2010) Afri. J. Biotech, 9(37), 6177-6181.

[19] Ibrahim A. M. (1984) Hydrobiologia, 110 : 113.

[20] Jobling M. (2002) Environmental factors and rates of development and growth. In Handbook of Fish Biology and Fisheries, 1. Hart, P.J.B, and Reynolds, J.D. (eds.). Blackwell Publishing, pp: 107-109.

[21] Kulbicki M., Guillemot N. and Amand M. (2005) Cybium, 29: 235-252.

[22] Kumolu-Johnson C.A., Ndimele P.E, Akintola S.L. and Jibuike C.C. (2010) Afr. J. Aqua. Sci, 35(1): 87-94.

[23] Lalèyè P.A. (2006) J.Appl. Ichtholo, 22: 330333.

[24] Le cren E.D. (1951) J. Anim. Ecol, 20(2): 201-219.
[25] Lizama M., De Los A.P. and Ambroso A.M. (2002) Braz. J. Biol, 62(1): 113-124.

[26] Mansor, M. I., Salmah M.R., Rosalina R., Shahrul A.M.S. and Amir S. R. S. (2010) Resch. J. Fish. and Hydro, 5(1): 1-8.

[27] Morey G., Moranta J., Massuti E., Grau A., Linde M., Riera F. and Morales-Nin B. (2003) Fish. Res. 62: 89-96.

[28] Ndimele P.E.,Kumolu- Johnson C.A., Aladetohun N.F. and Ayorinde O.A. (2010) Agric. Biol. J. N. Am,(4): 584-590.

[29] Oni S.K, Olayemi J.Y. and Adegboye J.D. (1983) J. Fish Biol, 22: 105-109.

[30] Pauly D. (1983) FAO Fisheries Tech. Pap., FAO. Rome, 234: 52.

[31] Pervin M.R. and Mortuza M.G. (2008) Univ. J. Zool. Rajshahi Univ, 27: 97-98.

[32] Richter H.C., Luckstadt C., Focken U., Becker K. (2000) Arch. Fish. Mar. Res. 48: 255-264.

[33] Rickter W.E. (1973) J. Fish. Res. Board Can, 30(3): 409-434.

[34] Saliu J.K. (2001) Trop. Freshwater Biol., 10: 9-17.

[35] Sandon H. (1950) Sudan Notes and Rec. $25: 61$.

[36] Thomas J., Venu S. and Kurup B.M. (2003) Length- weight relationship of some deepsea fish inhabiting the continental slope beyond 250m depth along the West Coast of India. NAGA, WorldFish Center Quaterly, 26(2): 17-21.

[37] Zar J.H. (1984) Biostatistical Analysis. Prentice Hall, New Jersey, pp: 718. 
Table 1- Estimated parameters of the length-weight relationships for six fish species in Atbara River and Kashm elGirba reservoir

\begin{tabular}{|c|c|c|c|c|c|c|c|c|c|}
\hline Family & Species & Locations & Station & $\ln a$ & $\mathrm{~b}$ & $\begin{array}{c}\text { S.E of } \\
b\end{array}$ & $\begin{array}{c}95 \% \text { of } \\
\text { C.I }\end{array}$ & $\mathrm{R}^{2}$ & G.P \\
\hline \multirow[t]{3}{*}{ Cyprinidae } & \multirow[t]{3}{*}{ Labeo niloticus } & \multirow{2}{*}{$\begin{array}{l}\text { Kashm el- Girba } \\
\text { reservoir }\end{array}$} & Remaila & -1.984 & 2.391 & 0.410 & 3.227 & 0.815 & $\mathrm{NA}$ \\
\hline & & & Bwadra & -1.945 & 2.940 & 0.247 & 2.438 & 0.895 & $\mathrm{NA}$ \\
\hline & & Atbara river & Umaswad & -1.688 & 2.911 & 0.286 & 2.491 & 0.839 & NA \\
\hline \multirow{3}{*}{ Synodontidae } & \multirow{3}{*}{ Synodontis schall } & \multirow{2}{*}{$\begin{array}{l}\text { Kashm el- Girba } \\
\text { reservoir }\end{array}$} & Remaila & -1.826 & 2.892 & 0.361 & 2.654 & 0.918 & $\mathrm{NA}$ \\
\hline & & & Bwadra & -5.793 & 3.522 & 0.173 & 3.888 & 0.960 & $\mathrm{PA}$ \\
\hline & & Atbara river & Umaswad & -2.988 & 2.628 & 0.390 & 3.497 & 0.819 & $\mathrm{NA}$ \\
\hline \multirow{3}{*}{ Auchenoglanidinae } & \multirow{3}{*}{$\begin{array}{c}\text { Auchenoglanis } \\
\text { biscutatus }\end{array}$} & \multirow{2}{*}{$\begin{array}{l}\text { Kashm el- Girba } \\
\text { reservoir }\end{array}$} & Remaila & -4.109 & 2.932 & 0.318 & 3.640 & 0.895 & $\mathrm{NA}$ \\
\hline & & & Bwadra & -3.453 & 2.697 & 0.416 & 3.554 & 0.827 & $\mathrm{NA}$ \\
\hline & & Atbara river & Umaswad & -4.974 & 3.165 & 1.139 & 3.789 & 0.920 & $\mathrm{PA}$ \\
\hline \multirow{3}{*}{ Clariidae } & \multirow{3}{*}{ Clarias lazera } & \multirow{2}{*}{$\begin{array}{l}\text { Kashm el- Girba } \\
\text { reservoir }\end{array}$} & Remaila & -6.061 & 3.317 & 0.072 & 3.501 & 0.998 & PA \\
\hline & & & Bwadra & -2.286 & 2.278 & 0.535 & 3.394 & 0.875 & $\mathrm{NA}$ \\
\hline & & Atbara river & Umaswad & -6.324 & 3.421 & 0.541 & 3.669 & 0.833 & PA \\
\hline \multirow[t]{3}{*}{ Cichlidae } & \multirow{3}{*}{$\begin{array}{l}\text { Oreochromis } \\
\text { niloticus }\end{array}$} & \multirow{2}{*}{$\begin{array}{l}\text { Kashm el- Girba } \\
\text { reservoir }\end{array}$} & Remaila & -5.346 & 3.648 & 0.752 & 3.885 & 0.922 & $\mathrm{PA}$ \\
\hline & & & Bwadra & -1.853 & 2.299 & 0.537 & 3.444 & 0.850 & NA \\
\hline & & Atbara river & Umaswad & 1.636 & 2.525 & 0.449 & 2.446 & 0.899 & $\mathrm{NA}$ \\
\hline \multirow{3}{*}{ Bagridae } & \multirow{3}{*}{ Bagrus bayad } & \multirow{2}{*}{$\begin{array}{l}\text { Kashm el- Girba } \\
\text { reservoir }\end{array}$} & Remaila & -3.836 & 2.857 & 0.170 & 3.248 & 0.972 & $\mathrm{NA}$ \\
\hline & & & Bwadra & -5.248 & 3.280 & 0.303 & 3.913 & 0.854 & PA \\
\hline & & Atbara river & Umaswad & -7.388 & 3.680 & 0.643 & 3.953 & 0.749 & PA \\
\hline
\end{tabular}

$\mathrm{a}=$ intercept of regression line, $\mathrm{b}=$ slope of regression line, S.E = Standard Error, $\mathrm{Cl}=$ confidence level, $\mathrm{R}^{2}=$ regression coefficient, $\mathrm{GP}=\mathrm{Growth}$ pattern, $\mathrm{PA}=$ positive allometric , $\mathrm{NA}=$ negative allometric.

Table 2- Growth performance of six species (TL\&W) and their values of mean relative condition factor with standard deviation $(K \pm s . d)$ collected from sampling sites in Atbara River and Kashm el-Girba reservoir.

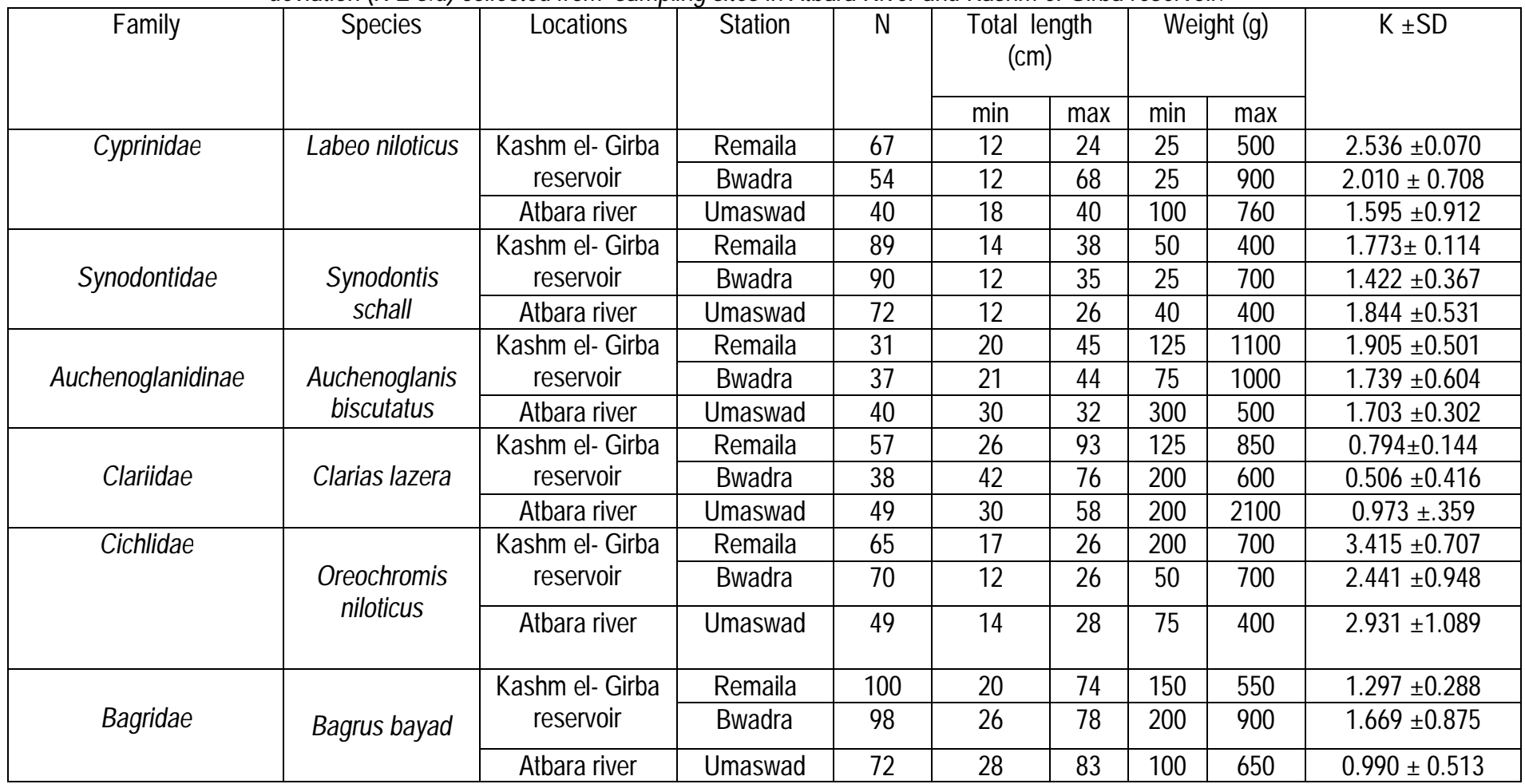

$\mathrm{N}=$ number of samples, $\min =$ minmum, $\max =\operatorname{maximum}, \mathrm{k}=$ condition factor, $\mathrm{SD}=$ standard deviation. 


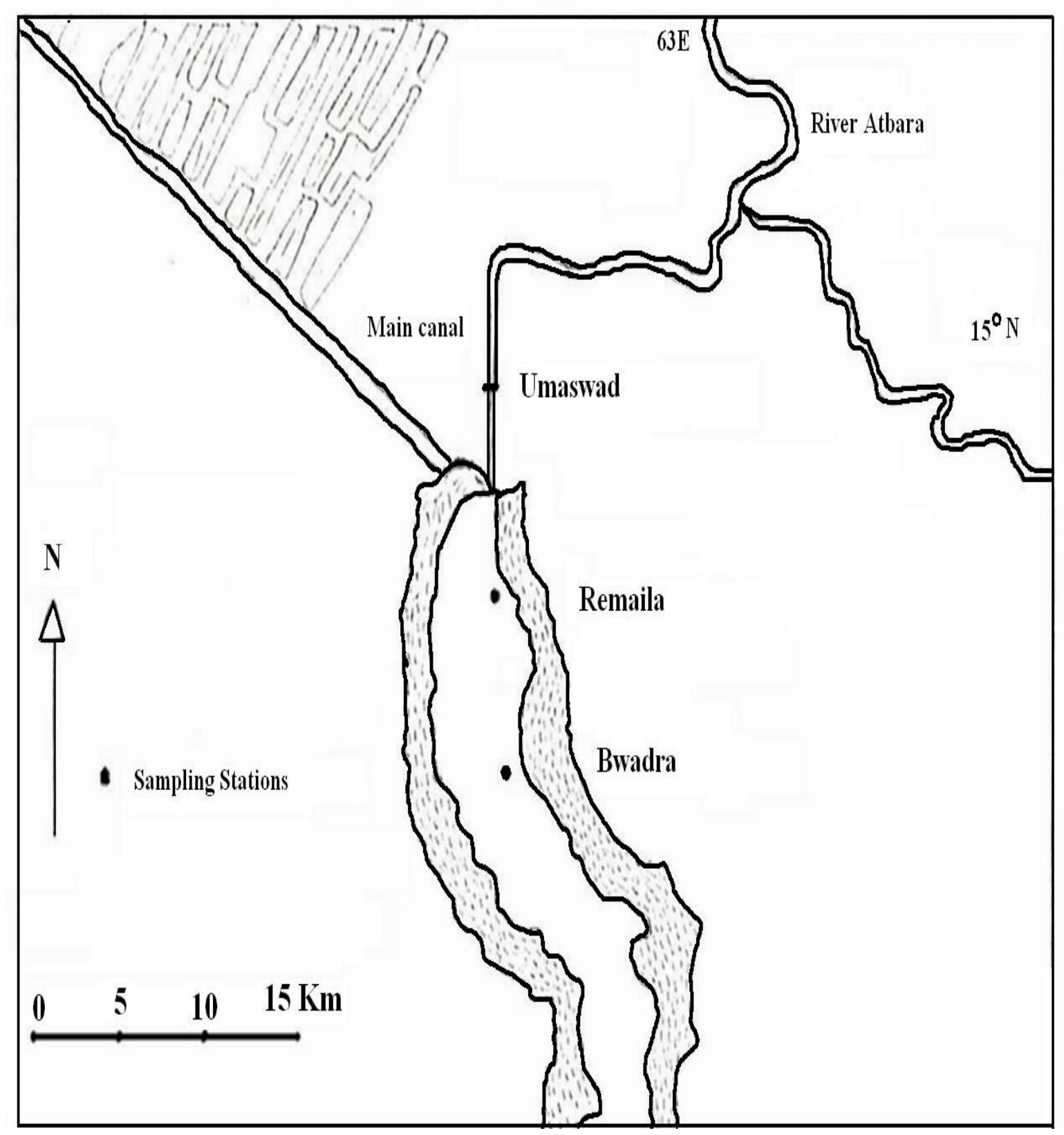

Fig. 1- Locations of study sites 